\title{
KEWENANGAN KREDITUR DALAM MENJUAL OBYEK JAMINAN TANAH DAN BANGUNAN LETTER C TANPA MELALUI LELANG
}

\author{
AUTHORITY OF CREDITORS IN SELLING WARRANTY OBJECTS, VIZ. LAND AND \\ BUILDINGS OF LETTER C WITHOUT AUCTION
}

\author{
Nuri Hidayati, Iwan Permadi, Budi Santoso \\ Program Studi Magister Ilmu Hukum Universitas Brawijaya \\ Jalan MT. Haryono 169, Malang \\ email: nurihidayati1994@gmail.com
}

\begin{abstract}
: the purpose of this study is to describe the authority of creditors to direct sell warranty objects in the form of land and building Letter C without passing the auction. This study uses normative juridical research methods that study and analyze the application of rules, acts, positive legal norms contained in legislation, jurisprudence, and contracts. This study uses a statutory approach, a conceptual approach, and a case approach. The results show that creditors are authorized to sell warranty objects in the form of land and Letter $\mathrm{C}$ buildings without auctions but through underhand sales.
\end{abstract}

Keywords: authority, creditor, sell warranty objects

\begin{abstract}
Abstrak: tujuan kajian ini adalah mendeskripsikan kewenangan kreditur menjual obyek jaminan berupa tanah dan bangunan Letter $C$ secara langsung tanpa melalui lelang. Kajian ini menggunakan metode penelitian yuridis normatif (hukum normatif) yang mengkaji dan menganalisis penerapan aturan, kaidah dan norma hukum positif yang terdapat dalam peraturan perundang-undangan, yurisprudensi (case law), dan kontrak. Pendekatan untuk menganalisis kajian ini adalah pendekatan perundang-undangan (statue approach), pendekatan konseptual (conceptual approach), dan pendekatan kasus (case approach). Hasil kajian menunjukkan bahwa kreditur berwenang menjual objek jaminan berupa tanah dan bangunan Letter $C$ tanpa melalui lelang, melainkan melalui penjualan di bawah tangan.
\end{abstract}

Kata Kunci: wewenang, kreditur, menjual objek jaminan

\section{PENDAHULUAN}

Dasar mengenai pengaturan tanah telah termuat pada Pasal 33 ayat (3) UndangUndang Dasar Negara Republik Indonesia 1945 yang berbunyi "Bumi, air, dan kekayaan alam yang terkandung di dalamnya dikuasai oleh negara dan dipergunakan untuk sebesarbesarnya kemakmuran rakyat". Seiring pertumbuhan dan perkembangan ekonomi khususnya di bidang bisnis, masyarakat serta pelaku pasar membutuhkan modal untuk membiayai dan mengelola bisnis mereka dengan mengadakan perjanjian kredit disertai jaminan antara masyarakat dengan lembaga perbankan. Hal utama dalam pemberian kredit adalah keyakinan bank sebagai kreditur terhadap debitur atau nasabah. Bank selaku pemberi kredit wajib memperhatikan karakteristik debitur dengan metode the five C's yang terdiri atas lima unsur: character (watak), capacity (kemampuan), capital (modal), collateral and condition of economic yaitu prospek usaha (Hariyani, 2010).

Salah satu kasus yang pernah terjadi adalah perjanjian kredit yang dibuat dengan disertai agunan atau jaminan berupa tanah dan bangunan bukti kepemilikan Letter $C$. Kasus yang diambil adalah Putusan Pengadilan Negeri Lumajang Nomor 41/ 
PDT.G/2015/PN.LMJ antara Ibu KMS sebagai nasabah (pihak penggugat) melawan PT.PNM Ulam Lumajang (tergugat I) dan EP (pihak pembeli obyek jaminan Letter $C$ (tergugat II). Perkara ini berawal dari adanya hubungan hukum perjanjian kredit yang dibuat secara di bawah tangan dengan Nomor 063/ULMLJKT/PK-MMR/XII/13 tanggal 24 Desember 2013 (PK 063) dengan pinjaman sebesar Rp50.000.000,00 (lima puluh juta rupiah) dengan memberikan agunan berupa tanah dan bangunan bukti kepemilikan Letter C Nomor 5318 Persil 762 Kelas D I berdasarkan Akta Hibah Nomor 12/HB/TII/2012, tanggal 13 Maret 2012 atas nama KMS dengan luas 540 meter persegi $\left(\mathrm{m}^{2}\right)$ yang terletak di Desa Kraton Kecamatan Yosowilangun Kabupaten Lumajang (selanjutnya disebut sebagai obyek jaminan).

Pada praktiknya, direktur direktorat kredit Bank Perkreditan Rakyat (BPR) ES mengatakan bahwa tanah yang masih belum bersertifikat seperti tanah dan bangunan bukti kepemilikan Letter $\mathrm{C}$ dapat dijadikan sebagai obyek jaminan perjanjian kredit tanpa melalui proses pendaftaran tanah terlebih dahulu yang kemudian diikat dengan akta pejabat umum (notaris/PPAT) berupa surat kuasa membebankan hak tanggungan (SKMHT), akta pemberian hak tanggungan dan sertifikat hak tanggungan (Antara, 2012). Namun proses pengikatan perjanjian kredit yang telah dilaksanakan tidak mematuhi aturan hukum yang diberlakukan dalam prosedur dan tata cara perjanjian kredit.

Pada proses pelunasan, KMS selaku debitur mengalami tunggakan angsuran yang tidak dibayarkan secara berkala sehingga dikategorikan kredit macet (Mahmoeddin, 2004). Tindakan KMS dinyatakan oleh kreditur sebagai wanprestasi (ingkar janji) akibat tidak dapat memenuhi prestasi sesuai dengan surat perjanjian antara kedua belah pihak. Bukti atas tindakan debitur yang melakukan wanprestasi dilihat dari tidak mengindahkannya surat peringatan penyelesaian tunggakan angsuran kredit sebanyak tiga kali selama tiga bulan terakhir.

Tindakan debitur yang melakukan wanprestasi membuat kreditur (PT PNM Ulam Lumajang) bergerak mengambil langkah dalam percepatan pelunasan piutangnya dengan menjual sendiri secara langsung di bawah tangan tanpa melalui lelang atas obyek jaminan tanah dan bangunan bukti kepemilikan Letter $C$ kepada tergugat II sebagai pihak pembeli tanpa sepengetahuan dan kesepakatan dari debitur. Tindakan kreditur tersebut mengakibatkan pihak debitur yang merasa keberatan mengajukan gugatan ke Pengadilan Negeri Lumajang. Seseorang atau suatu badan hukum apabila merasa hak-haknya dirugikan atau dilanggar oleh orang lain, salah satu jalan yang dapat ditempuh adalah perkara tersebut diajukan kepada hakim atau pengadilan negeri yang berwenang, yaitu dengan dibuatnya surat gugatan perdata (burgelijk vordering) (Saleh, 2012).

Debitur keberatan terhadap kreditur sehingga mengajukan gugatan ke pengadilan. Alasannya debitur merasa tidak pernah menjual objek jaminan atau agunan dan dianggap tindakan kreditur termasuk dalam perbuatan melawan hukum Pasal 1365 Kitab Undang-Undang Hukum Perdata yang. Pasal tersebut menyatakan Bahwa tiap perbuatan melawan hukum yang membawa kerugian kepada orang lain, mewajibkan orang karena salahnya menerbitkan kerugian itu, mengganti kerugian tersebut. Pihak kreditur dan pembeli telah merugikan penggugat akibat jual beli yang dilaksanakan tanpa sepengetahuan pihak debitur (penggugat).

Gugatan yang diajukan oleh debitur (penggugat) menjadikan jual beli obyek jaminan berupa tanah dan bangunan bukti kepemilikan Letter $C$ yang dilakukan oleh pihak kreditur (Bank PNM Ulam) dan pihak pembeli menjadi sengketa dan konflik di persidangan yang ditangani oleh majelis hakim karena debitur menganggap obyek sengketa masih menjadi haknya meskipun 
tidak pernah ada itikad baik untuk melunasi hutang, namun masih berkeinginan menguasai obyek sengketa.

Secara aturan hukum, penjualan obyek jaminan yang dilakukan secara langsung di bawah tangan hanya didasarkan pada perjanjian kredit di bawah tangan tanpa proses pengikatan akta notaris/PPAT, serta obyek jaminan tersebut masih tergolong tanah adat yang pembebanannya juga belum didaftarkan ke Badan Pertanahan Nasional (BPN). Berdasarkan latar belakang tersebut, tulisan ini akan membahas tentang kewenangan kreditur menjual obyek jaminan berupa tanah dan bangunan bukti kepemilikan Letter $C$ secara langsung tanpa melalui lelang.

\section{METODE}

Metode penelitian yang digunakan dalam kajian ini adalah penelitian yuridis normatif yang mengkaji dan menganalisis penerapan aturan, kaidah dan norma hukum positif yang terdapat dalam peraturan perundang-undangan, yurisprudensi (case law), dan kontrak. Pendekatan penelitian ini menggunakan pendekatan perundangundangan, pendekatan konseptual, dan pendekatan kasus. Pendekatan perundangundangan (statute approach) dilakukan dengan menelaah semua undang-undang dan regulasi yang berkaitan dengan isu hukum yang sedang ditangani. Pendekatan konseptual (conceptual approach) merujuk pada pandangan-pandangan dan doktrindoktrin yang berkembang dalam ilmu hukum (Marzuki, 2016). Pendekatan kasus (case approach) menelaah kasus-kasus yang berkaitan dengan isu hukum dari analisis putusan pengadilan yang memiliki kekuatan hukum tetap yaitu Putusan Pengadilan Negeri Lumajang No. 41/ PDT.G/2015/PN.LMJ.

Bahan hukum yang digunakan terdiri atas bahan hukum primer, sekunder, dan tersier (Marzuki, 2016). Bahan hukum primer ialah bahan hukum yang bersifat otoritatif artinya memiliki otoritas yang terdiri atas aturan hukum, catatan resmi atau risalah dalam pembuatan undang-undang, dan putusan hakim (Marzuki, 2010). Bahan hukum sekunder meliputi literatur dari buku-buku yang berisi pandangan atau doktrin, teori para ahli hukum, dan karya tulis berupa jurnal hukum, serta informasi yang diperoleh dari internet sebagai pedoman berpikir dalam menyusun sebuah argumentasi dalam kajian ini. Metode analisis bahan hukum yang digunakan adalah metode analisis interpretasi gramatikal dan interpretasi sistematis.

\section{HASIL DAN PEMBAHASAN}

\section{Kewenangan Kreditur Menjual Obyek Jaminan Tanah dan Bangunan Letter $C$ Tanpa Melalui Lelang}

Prosedur jual beli hak atas tanah telah diterapkan menurut ketentuan yang berlaku, yakni Undang-Undang Nomor 5 Tahun 1960 tentang Peraturan Dasar Pokok-Pokok Agraria (UUPA) dan Peraturan Pemerintah Nomor 24 Tahun 1997 tentang Pendaftaran Tanah (Hartanto, 2014). Jual beli tanah sebagai suatu lembaga hukum, tidak secara tegas dan terperinci diuraikan dalam UUPA. Namun dalam ketentuan Pasal 5 UUPA terdapat pernyataan bahwa hukum tanah nasional Negara Indonesia merupakan hukum adat yang telah disaneer dengan menggunakan konsepsi, asas-asas, atau lembaga hukum dan sistem hukum adat yang telah disempurnakan.

Berdasarkan hukum adat, jual beli tanah adalah suatu perbuatan pemindahan hak atas tanah yang bersifat terang dan tunai. Terang berarti perbuatan pemindahan hak tersebut harus dilakukan di hadapan kepala adat yang menanggung keteraturan dan sahnya perbuatan pemindahan hak, sehingga perbuatan tersebut diketahui oleh khalayak umum. Tunai maksudnya, bahwa perbuatan pemindahan hak dan pembayaran harganya dilakukan secara serentak. Oleh karenanya, tunai ditujukan 
harga tanah dibayar secara kontan atau baru dibayar sebagian. Dalam hal pembeli tidak membayar sisanya, maka penjual tidak dapat menuntut atas dasar terjadinya jual beli tanah, akan tetapi didasarkan pada hukum utang-piutang (Soekanto, 1983).

Praktik jual beli tanah dari obyek jaminan perbankan yang masih berstatus tanah hak lama berupa tanah dan bangunan bukti Letter $C$ yang status hak atas tanahnya belum bersertifikat yang penjualannya dilakukan secara langsung tanpa perantara lembaga lelang. Jual beli tersebut dilakukan atas dasar saling percaya antara kreditur dengan pembeli yang didasarkan jual beli tanah di bawah tangan. Hal ini tertuang dalam analisis Putusan Pengadilan Negeri Lumajang Nomor. 41/PDT.G/2015/PN.LMJ.

Berkenaan dengan sengketa pada kasus Putusan Pengadilan Negeri Lumajang No. 41/ Pdt.G/2015/PN.LMJ, tulisan ini akan mengkaji kewenangan kreditur menjual jaminan yang masih berbentuk tanah dan bangunan bukti kepemilikan Letter $C$ tanpa melalui pelelangan umum dengan penjualan di bawah tangan. Perjanjian kredit yang dilakukan adalah di bawah tangan yang tidak diikat/diikuti oleh akta autentik dari pejabat umum yaitu akta notaris/PPAT yang secara hukum tidak memiliki kekuatan mengikat. Hal tersebut menyebabkan kreditur tidak diutamakan untuk mendapatkan pelunasan hutang dibandingkan dengan kreditur lainnya. Namun hal itu tidak diindahkan oleh kreditur, sehingga dari perbuatan hukum yang telah dilakukan oleh kreditur dan debitur di atas, maka kreditur tidak memiliki kewenangan menjual obyek jaminan kepada pihak pembeli dengan alasan apapun.

Mengenai ketidakwenangan subyek hukum bagi badan hukum (PT PNM Ulam Lumajang) yang bertindak menjual obyek jaminan dalam perjanjian kredit didasarkan pada ketidakpercayaan dalam bertindak dan ketidakberwenangan untuk bertindak. Ketidakcakapan dalam bertindak (handeling onbekwaamheid) artinya kreditur tidak berwenang untuk bertindak menjual obyek jaminan perjanjian kredit secara langsung kepada pihak ketiga (pembeli) tanpa melalui perantara kantor lelang (KPKNL) ataupun titel eksekutorial dari pengadilan negeri. Karena kewenangan bertindak tentang eksekusi (menjual) obyek jaminan telah diatur dalam peraturan perundang-undangan berdasarkan fungsi dan tugasnya yang tercantum pada Pasal 20 ayat (1) huruf a dan b dan Pasal 20 Ayat (2) UUHT tentang eksekusi hak tanggungan. Pasal tersebut mengatur apabila debitur cidera janji, maka pemegang hak tanggungan pertama memiliki hak untuk menjual obyek hak tanggungan sebagaimana dimaksud dalam pasal 6 . Dalam titel eksekutorial yang terdapat dalam sertifikat hak tanggungan, obyek hak tanggungan dijual melalui pelelangan umum menurut tata cara yang ditentukan dalam peraturan perundang-undangan untuk pelunasan piutang pemegang hak tanggungan dengan hak mendahului dari pada kreditur lainnya sebagaimana dimaksud dalam Pasal 14 Ayat (2). Atas kesepakatan pemberi dan pemegang hak tanggungan, penjualan obyek hak tanggungan dapat dilaksanakan di bawah tangan sehingga akan dapat diperoleh harga tertinggi yang menguntungkan semua pihak.

Ketentuan Pasal 20 Ayat (1) huruf a dan b serta Pasal 20 Ayat (2) UUHT merupakan perwujudan dari kemudahan yang disediakan oleh undang-undang ini bagi para kreditur pemegang hak tanggungan. Pada prinsipnya setiap eksekusi harus dilaksanakan melalui pelelangan umum baik secara titel eksekutorial (lelang melalui pengadilan negeri) ataupun melalui kantor lelang (KPKNL). Melalui cara ini diharapkan dapat diperoleh harga yang paling tinggi untuk obyek hak tanggungan. Kreditur berhak mengambil pelunasan piutang yang dijamin dari hasil penjualan obyek hak tanggungan. Hasilnya penjualan itu lebih besar daripada piutang tersebut yang 
setinggi-tingginya sebesar nilai tanggungan, sisanya menjadi hak pemberi hak tanggungan (debitur), sehingga secara aturan hukum yang berhak dan berwenang menjalankan eksekusi hak tanggungan ialah lembaga/ instansi lelang dan pengadilan negeri yang telah ditunjuk oleh undang-undang sebagai lembaga eksekusi (titel eksekutorial).

Ketentuan Pasal 20 ayat (2) UUHT perihal penjualan obyek hak tanggungan melalui pelelangan umum diperkirakan tidak akan menghasilkan harga tertinggi, maka kantor lelang (KPKNL) atau pengadilan negeri diberi kemungkinan untuk melakukan eksekusi melalui penjualan di bawah tangan, asalkan hal tersebut disepakati oleh pemberi (debitur atau nasabah) dan pemegang hak tanggungan (kreditur) dengan syarat-syarat yang ditentukan pada Pasal 20 ayat (3) UUHT dipenuhi. Kemungkinan ini dimaksudkan untuk mempercepat penjualan obyek hak tanggungan dengan harga penjualan tertinggi sehingga eksekusi dengan cara penjualan di bawah tangan merupakan alternatif bagi para pihak yang tidak menginginkan jaminannya dieksekusi (dijual) melalui kantor lelang atau titel eksekutorial. Kewenangannya berada pada kesepakatan/persetujuan para pihak (kreditur dan debitur) dalam pengadaannya, sehingga dapat dilakukan proses eksekusi obyek jaminan dengan cara penjualan di bawah tangan (Harahap, 2013).

Aturan-aturan hukum yang diberlakukan memiliki sasaran yang hendak dicapai guna menciptakan tatanan masyarakat yang tertib, seimbang, dan berkesinambungan. Dengan tercapainya ketertiban di dalam masyarakat, diharapkan kepentingan setiap individu akan terlindungi sehingga. Untuk mencapai hal tersebut, hukum bertugas membagi hak dan kewajiban orang perorangan (individu), membagi wewenang, mengatur tata cara memecahkan masalah-masalah hukum dengan sebuah solusi (problem solving), serta memelihara kepastian hukum dalam aturan hukum yang telah diberlakukan (Mertokusumo, 2005).
Dalam kasus ini, ketidakberwenangan untuk bertindak (handeling onbevoegheid) ditujukan kepada kreditur (PT PNM Ulam Lumajang) selaku badan hukum yang melakukan tindakan menjual (mengeksekusi) jaminan yang masih berupa tanah adat (tanah Letter C) kepada pihak pembeli dengan sistem penjualan di bawah tangan. Tindakan PT PNM Ulam Lumajang ini merupakan perbuatan melawan hukum (PMH) sebagaimana tertera dalam Pasal 1365 KUH Perdata yaitu (a) bertentangan dengan kewajiban hukum si pelaku, (b) melanggar hak subjektif orang lain, (c) melanggar kaidah tata susila, dan (d) bertentangan dengan asas kepatutan, ketelitian dan kehati-hatian.

Tindakan PT PNM Ulam Lumajang merupakan tindakan bertentangan dengan kewajiban hukum pelaku karena pengadaan perjanjian kredit yang dilakukan hanya berdasarkan pada perjanjian kredit di bawah tangan. Hal ini menjadikan posisi kreditur lemah dan kedudukannya sama dengan kreditur-kreditur lain (kreditur konkuren). Kreditur tidak memiliki kewenangan untuk menjual jaminan tersebut meskipun debitur melakukan tindakan wanprestasi. Proses penjualan obyek jaminan menjadi kewajiban hukum lembaga/instansi kantor lelang (KPKNL) atau pengadilan negeri dengan cara titel eksekutorial merupakan akibat dari perjanjian kredit yang dibuat tanpa diikat oleh akta autentik dari pejabat umum.

Tindakan PT PNM Ulam Lumajang yang menjual obyek jaminan tanpa sepengetahuan pemilik (debitur) merupakan perbuatan melanggar hak subjektif pihak lain. Meskipun tindakan debitur telah dinyatakan wanprestasi karena tidak dapat melanjutkan angsuran yang tertunda, akan tetapi hal yang harus dilakukan terlebih dahulu adalah melakukan musyawarah (berunding) untuk mencari solusi dan alternatif cara yang tepat agar dapat melunasi utang debitur.

Tindakan PT PNM Ulam Lumajang termasuk melanggar kaidah tata susila. 
Tindakan kreditur melakukan penjualan atas tanah jaminan yang masih milik debitur yang dilakukan dengan penjualan di bawah tangan melanggar aturan hukum jaminan dan tata cara eksekusi hak tanggungan yang telah ditetapkan oleh undang-undang dalam pelaksanaannya.

Tindakan PT PNM Ulam Lumajang juga bertentangan dengan asas kepatutan, ketelitian dan kehati-hatian. Hal ini bersumber pada hukum tidak tertulis yaitu pengikatan perjanjian kredit perbankan dengan dasar perjanjian utang piutang hanya didasarkan sebuah formulir perjanjian kredit yang pada dasarnya tidak memiliki kekuatan hukum mengikat jika tidak diikat oleh akta notaris/PPAT. Demikian itu menunjukkan kreditur tidak cermat dalam aturan hukum pengikatan kredit dan kurang memahami asas kehati-hatian dalam memberikan persetujuan kredit.

Tindakan jual beli kreditur dengan pembeli dinyatakan sebagai perbuatan melawan hukum karena kreditur tidak memiliki kewenangan untuk bertindak menjual obyek jaminan. Tindakan kreditur tidak sesuai dengan aturan perundangundangan serta tidak sesuai dengan tugas dan fungsinya sebagai badan hukum yang telah didirikan. Dilihat dari fungsinya, bank berfungsi dalam pengerahan dan fungsi penyaluran dana untuk menopang perekonomian masyarakat. Selain itu, perbuatan jual beli yang dilakukan oleh kreditur dengan pembeli tanpa sepengetahuan dan persetujuan pihak debitur masuk dalam kategori penyalahgunaan wewenang dan melanggar hukum.

Mengenai kewenangan yang dapat dilakukan oleh pihak kreditur atas perjanjian kredit berdasar perjanjian utang piutang yang dibuat hanya di bawah tangan tanpa pengikatan akta notaris ialah hanya dapat mengajukan gugatan atau tuntutan perdata ke pengadilan negeri. Dalil gugatan menyatakan bahwa debitur telah melakukan tindakan wanprestasi (ingkar janji) yang didasarkan pada bukti surat peringatan (somasi) sebanyak tiga kali yang diberikan kreditur kepada debitur sebagai teguran agar debitur melunasi utangnya, namun diabaikan oleh kreditur.

Untuk menyelesaikan kredit bermasalah dapat ditempuh dengan dua cara yaitu penyelamatan kredit dan penyelesaian kredit. Penyelamatan kredit adalah suatu langkah penyelesaian kredit bermasalah melalui perundingan kembali antara kreditur dan debitur, sedangkan penyelesaian kredit adalah suatu langkah penyelesaian kredit bermasalah melalui lembaga hukum. Lembaga hukum dalam hal ini ialah Panitia Urusan Piutang Negara (PUPN), Direktorat Jenderal Piutang dan Lelang Negara (DJPLN) yang sekarang disebut sebagai Kantor Pelayanan Kekayaan Negara dan Lelang (KPKNL), badan peradilan, dan badan arbitrase atau badan alternatif penyelesaian sengketa (Hermansyah, 2008).

Penyelamatan kredit bermasalah dapat dilakukan dengan berpedoman kepada Surat Edaran Bank Indonesia Nomor 26/4/ BPPP tanggal 29 Mei 1993. Sebelum diselesaikan melalui lembaga-lembaga hukum, penyelamatan kredit bermasalah dapat diselesaikan melalui alternatif penanganan yaitu rescheduling, reconditioning, dan restructuring. Rescheduling (penjadwalan kembali), yaitu suatu upaya hukum untuk melakukan perubahan terhadap beberapa syarat perjanjian kredit yang berkenaan dengan jadwal pembayaran kembali atau jangka waktu kredit termasuk tenggang (grace period) dan perubahan jumlah angsuran apabila perlu penambahan kredit. Reconditioning (persyaratan kembali), yaitu melakukan perubahan atas sebagian atau seluruh persyaratan perjanjian, yang tidak terbatas hanya kepada perubahan jadwal angsuran, dan/atau jangka waktu kredit saja. Akan tetapi perubahan kredit tersebut tanpa memberikan konversi atas seluruh atau sebagian dari kredit menjadi equity perusahaan. Restructuring (penataan kembali), yaitu upaya untuk melakukan 
perubahan syarat-syarat perjanjian kredit berupa pemberian tambahan kredit atau melakukan konversi atas seluruh/sebagian kredit yang dilakukan dengan atau tanpa rescheduling, dan/atau reconditioning (Hermansyah, 2008).

Penyelesaian kredit bermasalah adalah langkah terakhir yang dapat dilakukan setelah langkah-langkah penyelamatan kredit bermasalah yang berupa restrukturisasi tidak efektif lagi. Penyelesaian kredit bermasalah melalui lembaga hukum memerlukan waktu yang relatif lama karena kepastian hukumnya baru ada setelah putusan pengadilan itu memperoleh kekuatan hukum tetap/inkraacht van bewijs (Hermansyah, 2008).

Penyelesaian kredit bermasalah juga dapat dilakukan melalui lembaga-lembaga lain seperti lembaga arbitrase dan badan alternatif penyelesaian sengketa yang berkompeten dalam membantu menyelesaikan masalah-masalah kredit (Hermansyah, 2008). Kehadiran dari lembaga-lembaga lain ini dimaksudkan dapat mewakili kepentingan kreditur dan debitur dalam penanganan kredit macet.

Kewenangan kreditur untuk menjual (mengeksekusi) obyek jaminan perjanjian kredit yang berupa tanah dan bangunan bukti kepemilikan Letter $C$, diatur dalam Pasal 20 ayat (2) UUHT. Ketentuan pasal ini diberlakukan apabila penjualan melalui pelelangan umum diperkirakan tidak akan menghasilkan harga tertinggi dari hasil penjualan lelang tersebut. Kreditur diberi kemungkinan untuk melakukan eksekusi jaminan melalui penjualan di bawah tangan, asalkan hal tersebut telah terlebih dahulu disepakati (disetujui) oleh pemberi hak tanggungan (debitur) dan pemegang hak tanggungan (kreditur), serta syarat yang ditentukan pada Pasal 20 Ayat (3), antara lain: mengadakan pengumuman melalui surat kabar atau media massa lainnya dan diumumkan sekurang-kurangnya dalam dua surat kabar (Penjelasan Umum Pasal 20 ayat (3) UUHT).
Pelaksanaan penjualan di bawah tangan menurut ketentuan Pasal 20 Ayat (3) UUHT dapat dilakukan setelah lewat waktu satu bulan sejak diberitahukan secara tertulis oleh pemberi dan/atau pemegang hak tanggungan kepada pihak-pihak yang berkepentingan seperti pemegang hak tanggungan kedua, ketiga, dan krediturkreditur lain dari pemberi hak tanggungan. Tanggal pemberitahuan tertulis ialah tanggal pengiriman pos tercatat/tanggal penerimaan melalui kurir ataupun tanggal pengiriman faksimile. Pelaksanaannya wajib diumumkan sekurang-kurangnya dalam dua surat kabar/ media massa seperti koran, televisi, radio di daerah yang bersangkutan dengan sebuah pernyataan tidak keberatan kepada para pihak atas penjualan di bawah tangan yang dilakukan (Harahap, 2013). Jangkauan surat kabar dan media massa yang dipergunakan harus meliputi tempat letak obyek hak tanggungan yang bersangkutan serta tidak ada pihak yang menyatakan keberatan.

Cara penjualan jaminan secara di bawah tangan dimaksudkan untuk mempercepat penjualan obyek jaminan sehingga diharapkan memperoleh harga penjualan tertinggi dan menguntungkan semua pihak (Sutedi, 2012). Ketentuan memungkinkan kreditur untuk dapat melakukan penjualan obyek jaminan secara di bawah tangan guna mendapatkan sebagian pelunasan piutangnya dari pihak debitur. Apabila kondisi debitur dinyatakan sudah tidak sanggup lagi melunasi utangnya kepada kreditur dan satu-satunya aset atau harta benda yang dimiliki pihak debitur hanya benda jaminan tersebut yaitu tanah dan bangunan bukti kepemilikan Letter $C$, maka jalan alternatif bagi pihak debitur untuk dapat melunasinya hanya dengan melakukan penjualan obyek jaminan sebagai solusi untuk tidak merugikan pihak kreditur.

Penjualan obyek hak tanggungan di bawah tangan merupakan penjualan yang tidak melalui pelelangan umum, jual beli dilakukan secara sukarela oleh pihak penjual (kreditur) dan pihak pembeli (sebagai pihak 
ketiga). Istilah di bawah tangan maksudnya transaksi peralihan hak terjadi dengan pembubuhan tanda tangan pihak penjual (kreditur) dan pihak pembeli pada akta jual beli (Sutedi, 2012). Sistem penjualan jaminan secara di bawah tangan diatur dalam Pasal 20 ayat (2) dan (3) UUHT yang pelaksanaan mempertimbangkan beberapa hal, antara lain: (1) adanya kesepakatan antara pihak pemberi dan pemegang hak tanggungan, (2) bentuk kesepakatan, (3) perkiraan harga yang tertinggi, dan (4) pelaksanaan penjualan.

Kesepakatan antar pihak ditujukan untuk mempercepat penjualan obyek jaminan dan untuk mengurangi pengeluaran biaya eksekusi yang harus ditanggung debitur. Kesepakatan dapat dibuat setelah terjadi ingkar janji namun tidak boleh dituangkan dalam akta pemberian hak tanggungan. Artinya proses jual beli secara di bawah tangan baru dapat dilakukan apabila terlebih dahulu terjadi wanprestasi (Harahap, 2013).

Bentuk kesepakatan dapat dituangkan secara tertulis (in writing) dalam bentuk akta di bawah tangan atau akta autentik, dapat berbentuk telegram, teleks, atau faksimile. Bentuk kesepakatan dapat dituangkan dalam persetujuan bersama, dapat juga dalam surat persetujuan terpisah.

Penjualan yang dilakukan diharapkan memperoleh harga yang baik dan tidak merugikan pihak debitur. Kebebasan penjualan di bawah tangan berdasarkan kesepakatan telah digariskan pada ketentuan peraturan perundang-undangan yang termuat dalam Pasal 20 Ayat (2) UUHT, dengan harapan penjualan yang dilakukan secara di bawah tangan dapat memperoleh harga yang lebih baik atau harga yang lebih menguntungkan (Harahap, 2013).

Pengaturan dari penjualan di bawah tangan jika dibandingkan dengan eksekusi hak tanggungan melalui lembaga hukum seperti lelang titel eksekutorial (pengadilan negeri) maupun pelelangan umum (kantor lelang KPKNL) dinilai lebih baik karena lima alasan yaitu: (a) proses eksekusi di pengadilan cukup lama, (b) proses pelelangan oleh juru lelang (pejabat lelang) relatif masih kurang baik, (c) biaya eksekusi dan biaya pelelangan (bea pajak, dan lain-lain) sangat tinggi, (d) keadaan obyek hak tanggungan pada umumnya masih tergolong baik dalam arti menutup utang dan marketable, (e) pembelian obyek hak tanggungan oleh kreditur bank swasta belum berdasarkan peraturan perundang-undangan yang berlaku efektif (Sutedi, 2012).

Ketentuan penjualan di bawah tangan dilaksanakan untuk melindungi kepentingan pihak debitur (sebagai nasabah perbankan) dari kewenangan pemegang hak tanggungan (kreditur). Sejak awal, pencantuman dari adanya aturan penjualan di bawah tangan diharapkan mampu mengurangi keleluasaan pihak kreditur dari tindakan penjualan obyek jaminan secara semena-mena yang dapat merugikan pihak debitur. Dalam hal penjualan dilakukan di bawah tangan, harga penjualan sebaiknya tidak ditetapkan sendiri oleh bank, tetapi berdasarkan kesepakatan para pihak (kreditur dan debitur) atau berdasarkan penilaian harga oleh suatu perusahaan penilai yang independen (Sutedi, 2012).

\section{SIMPULAN}

Kreditur berwenang menjual obyek jaminan berupa tanah dan bangunan bukti kepemilikan Letter $C$ tanpa melalui pelelangan baik lelang titel eksekutorial maupun pelelangan umum. Ketentuan penjualan obyek jaminan dapat dilakukan apabila mendapatkan persetujuan dari pihak debitur serta memenuhi syarat yang ditentukan pada Pasal 20 Ayat (3) UUHT.

\section{DAFTAR RUJUKAN}

Antara. (2012). Girik Bisa Jadi Agunan UKM ke BPR. Berita Satu. https:// www.beritasatu.com/ekonomi/28607girik-bisa-jadi-agunan-ukm-ke-bpr. html

Harahap, M. Y. (2013). Ruang Lingkup 
Permasalahan Eksekusi Bidang Perdata. Sinar Grafika

Hariyani, I. (2010). Restrukturisasi dan Penghapusan Kredit Macet. Elex Media Kompterindo Kompas.

Hartanto, A. (2014). Hukum Pertanahan Karakteristik Jual Beli Tanah Yang Belum Terdaftar Hak Atas Tanahnya. Lakbang Justitia.

Hermansyah. (2008). Hukum Perbankan Nasional Indonesia, Edisi Revisi Cetakan Ke IV (Vol. 2008). Kencana.

Mahmoeddin, A. (2004). Melacak Kredit Bermasalah. Pustaka Sinar Harapan.
Marzuki, P. M. (2010). Penelitian Hukum. Kencana Prenada Media Group.

Marzuki, P. M. (2016). Penelitian Hukum. Kencana Prenada Media Group.

Mertokusumo, S. (2005). Mengenal Hukum Suatu Pengantar. Liberty Yogyakarta.

Saleh, M. dan M. L. (2012). Bunga Rampai Hukum Acara Perdata Indonesia: Perspektif, Teoritis, Praktik dan Permasalahannya. Alumni.

Soekanto, S. (1983). Hukum Adat Indonesia. Rajawali Pers.

Sutedi, A. (2012). Hukum Hak Tanggung an Edisi 1 Cetakan 2. Sinar Grafika. 